\title{
Selecting Environmental Water Tracers to Understand Groundwater around Mines: Opportunities and Limitations
}

\author{
Devmi Kurukulasuriya $^{1}$ (]) $\cdot$ William Howcroft $^{1} \cdot$ Ellen Moon $^{1} \cdot$ Karina Meredith $^{2} \cdot$ Wendy Timms $^{1}$
}

Received: 2 August 2021 / Accepted: 18 January 2022 / Published online: 7 February 2022

(c) The Author(s) 2022

\begin{abstract}
Underground mining operations have the potential to alter groundwater systems and facilitate hydraulic connections between surface water and groundwater. The nature and degree of these interactions need to be evaluated to identify mining risks to surrounding water resources and to predict potential operational effects and environmental impacts, such as hydraulic stress on local surface waters. Environmental water tracers (EWTs) are commonly used to study such interactions in mine water and hydrogeological studies. However, the opportunities presented by EWTs could be more widely utilised to benefit the mining industry and the environment. Some of the challenges faced include the lack of practical frameworks, the need for more examples of EWTs applications in mining, and the possibility of complex interpretation of tracer results. This paper reviews previous studies that have applied EWTs in groundwater systems within or near mine sites, mostly from Australia, China, and India. The EWTs used in these studies include water quality parameters, major ions, stable isotopes, radioisotopes, and dissolved gases. The opportunities of applying multiple EWTs to identify water sources, mixing, and determine recharge rates and groundwater residence times are discussed. Limitations of different EWTs in terms of their capabilities, reliability, cost of analysis, effort, and processing times are reviewed. Steps for selecting suitable EWTs for specific mine hydrogeology assessments should be commensurate with the risks. Finally, this paper provides an overview of suitable EWTs that will be a useful contribution to appropriate water resource management decisions around mines.
\end{abstract}

Keywords Surface water-groundwater interactions $\cdot$ Inter-aquifer connections $\cdot$ Isotopes $\cdot$ EWTs

\section{Introduction}

Understanding hydraulic connectivity in surface water and groundwater (SW-GW) systems is essential before and during mining operations but is often complex and challenging. These interactions can have significant implications for both the water quantity and quality of the interconnected water assets (Brodie et al. 2007; Younger and Wolkersdorfer 2004). Naturally, SW-GW interact under different physical, geographic, topographic, and climatic settings and are not considered isolated or separate (Sophocleous 2002). When a stream is hydraulically connected to a shallow groundwater system, the stream can be either gaining or losing water

Devmi Kurukulasuriya

dkurukulasuriya@deakin.edu.au

Deakin University, Waurn Ponds, VIC 3216, Australia

2 Australian Nuclear Science and Technology Organisation, Institute for Environmental Research, Lucas Heights, NSW 2232, Australia flow depending on the climate and catchment hydrogeology (Fetter 1994). Strong hydraulic connections may also occur between shallow and deep aquifers and the interactions may be complex in a multi-layered system, due to the aquifer being confined or unconfined, and the presence of aquitards and geological features such as faults and folds (Sayed et al. 1992). Mining can increase hydraulic connections between SW-GW.

Changes to the aquifer structure are caused by excavations (directly) and mining-induced subsidence (indirectly). Consequently, higher hydraulic conductivities and lower storage capacities alter the natural groundwater flow paths and rates (Booth 2006; Tammetta 2015, 2016; Zhang and López 2019). Subsidence can further enhance existing fractures within the overlying strata and cause new fractures that extend upward to streambeds, resulting in the leakage of streamflow into the subsurface (Jankowski and Knights 2010). Understanding these interactions is essential to avoid double accounting in water budgets and underestimating the effects of mining operations (Banks et al. 2008). The 
responses observed in large groundwater systems due to anthropogenic stresses can be predicted using mathematical groundwater flow models based on flow principles and hydraulic parameters. However, the interconnections due to higher frequency of fracturing produced by excavations during mining add complexity and uncertainty to groundwater flow. As a result, the underlying conceptual models of the groundwater system tend to be oversimplified, and groundwater flow models may not be suitable for predicting water table drawdown at a local scale due to large predictive uncertainty (Middlemis and Peeters 2018). Due to the uncertainties in developing models in these environments, the use of independent monitoring techniques are increasingly recommended by industry experts (Office of Water Science 2020) and regulatory agencies (Brodie et al. 2007).

EWTs are naturally present, identifiable substances in water whose behaviour can be studied to infer properties about water (Evans 1983). EWTs can be part of the water molecule or dissolved within the water. The choice of suitable EWTs must correspond to the level of risks in mining operations, including the vulnerability and proximity of high-value aquifers and surface water resources (Timms et al. 2012). The adoption of EWTs for groundwater investigations in the mining industry has been variable, with some mining sectors becoming faster adopters than others. Possible reasons are the perceived associated high cost of sampling and analysis and the technical expertise required for interpretation (Brodie et al. 2007). It has been reported that the Australian coal and unconventional gas development sector is open to considering the potential benefits of EWTs, but raise concerns over targeting suitable use on needs basis (Lamontagne and Mallants 2018). This type of feedback from the industry suggests the need to demonstrate the benefits and limitations of the various EWTs to evaluate SW-GW interactions and inter-aquifer connections in mine sites.

This paper describes suites of EWTs used widely in groundwater studies and provides a review of their applications in the mining industry. Specifically, this paper focuses on the stages before and during mining operations and applying EWTs to understand SW-GW interactions and inter-aquifer connections. Very few studies have focussed on the application of advanced EWTs in the mining industry. Wolkersdorfer et al. (2020) summarised a broader range of hydrogeological applications of EWTs in the mining industry, but here we focus directly on using EWTs to evaluate the groundwater flow and surface connections around mines. The use of EWTs in reactive transport modelling or the calibration of groundwater flow models are outside the scope of this paper. The main aim of this paper is to provide a comparative tool that will support the decision-making process for the selection of suitable EWTs, commensurate with risks to mining operations and to environmental and water assets.

\section{Environmental Water Tracers}

EWTs include physical water quality parameters, dissolved gases, major ion chemistry, and isotopes of elements. Isotopes are atoms with same number of protons and electrons but a different number of neutrons. There is a quantifiable difference between the mass of each isotope, which leads to naturally different abundances, and the isotopes behaving differently during physical, chemical, and biological processes (Appelo and Postma 2004).

The International Atomic Energy Agency (2016) developed three categorises for EWTs based on the purpose of the application. The first group are routinely used in groundwater quality monitoring. The second and third groups of EWTs are used for more detailed water chemistry investigations. Similarly, in this paper EWTs will be referred to as; primary EWTs (water quality parameters, major ions, and stable isotopes), investigation EWTs (e.g. dissolved gases), and advanced EWTs (e.g. radioisotopes and noble gas isotopes). However, the list of EWTs for each group have been revised and are not intended to be prescriptive or exclusive. The investigation group is considered to be generally inclusive of the primary group and the advanced group is inclusive of both the investigation and primary groups (Fig. 1). Ideally, tracers from each group should be used in mine site investigations to provide the most accurate interpretation of the groundwater system.

\section{Primary EWTs}

Physiochemical parameters such as $\mathrm{pH}$, temperature ( $\mathrm{T})$, dissolved oxygen (DO), and electrical conductivity (EC) are

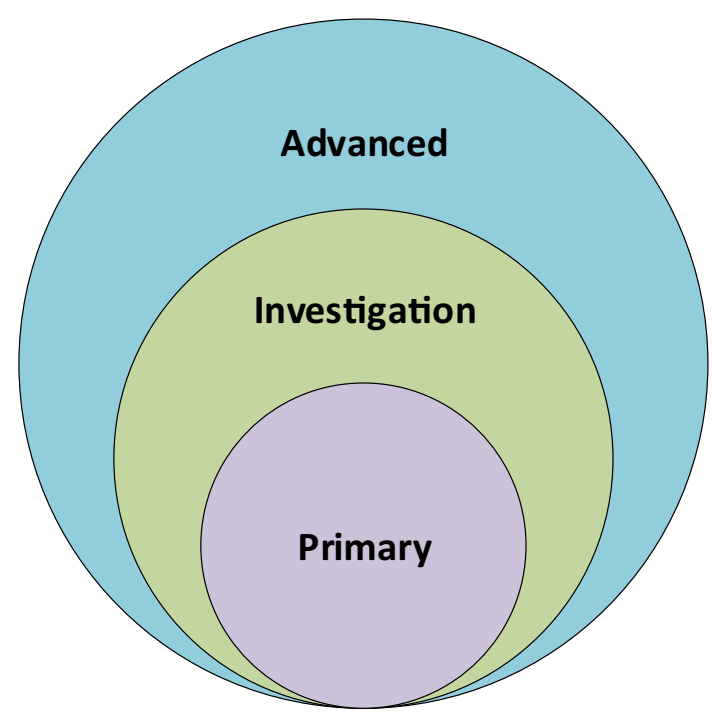

Fig. 1 A conceptual diagram of the EWT classification 
commonly used to understand the water quality and provide in-field indications of water sources, flow paths, and potential geochemical processes. Similarly, major ion chemistry ( $\mathrm{Na}, \mathrm{Mg}, \mathrm{Ca}, \mathrm{K}, \mathrm{Cl}, \mathrm{HCO}_{3}, \mathrm{CO}_{3}$, and $\mathrm{SO}_{4}$ ) can be used to determine dominant processes controlling the water chemistry of a sample, such as water-rock interactions (Gibbs 1970). Trace elements ( $\mathrm{Sr}, \mathrm{Li}, \mathrm{Si}, \mathrm{B})$ and metal concentrations $(\mathrm{Zn}, \mathrm{Ni}, \mathrm{Cu}, \mathrm{Fe})$ can be used to understand water-sediment processes and trace sources of mine water contamination from potentially toxic metals.

Stable isotopes of oxygen-18 $\left(\delta^{18} \mathrm{O}\right)$ and deuterium $\left(\delta^{2} \mathrm{H}\right)$ are naturally occurring and are not radioactive isotopes, and can be used to trace the hydrological cycle and origins of groundwater (Clark and Fritz 1997). The isotopic signatures of $\delta^{18} \mathrm{O}$ and $\delta^{2} \mathrm{H}$ vary based on meteorological processes, such as condensation, evaporation, temperature, and elevation (Craig 1961). The origin of groundwater can be identified using these isotopes when the local precipitation values of $\delta^{18} \mathrm{O}$ and $\delta^{2} \mathrm{H}$ are known. The stable isotopes of carbon $\left(\delta^{13} \mathrm{C}\right)$ are measured in both dissolved inorganic carbon (DIC) and dissolved organic carbon (DOC) to characterize water-rock interactions and geochemical processes taking place within the subsurface. The $\delta^{13} \mathrm{C}$ values can also be used to give insights into geochemical processes involving carbon when estimating groundwater residence times using radiocarbon (Meredith et al. 2016).

\section{Investigation EWTs}

Investigation EWTs include dissolved anthropogenic gases such as chlorofluorocarbons (CFCs) and sulfur hexafluoride $\left(\mathrm{SF}_{6}\right)$. The atmospheric concentrations of $\mathrm{CFC}$ have declined since production began in the 1950s for industrial and domestic purposes such as refrigeration and air conditioning. These synthetic chemicals were identified as greenhouse gases and were subsequently phased out (Chambers et al. 2019). Conversely, $\mathrm{SF}_{6}$ production and release to the atmosphere increased because of their use in the electrical manufacturing industry. $\mathrm{CFC}$ and $\mathrm{SF}_{6}$ gases dissolve and equilibrate via precipitation, acquiring unique compositions following Henry's law (Busenberg and Plummer 1992). The concentration of $\mathrm{CFCs}$ and $\mathrm{SF}_{6}$ in groundwater is indicative of the time since the water was last in contact with the atmosphere and can be used as a guide for recharge timing (the higher the concentrations, the younger the water). The recharge date can be estimated using the known input rates of gases and Henry's solubility calculations, based on the temperature, pressure (elevation), excess air, and salinity (Plummer and Busenberg 2006). A thorough guide on the use of CFC can be found in International Atomic Energy Agency (2006). Since the atmospheric CFC concentrations have reached a constant, there is non-uniqueness in the relationship between time and concentration. Therefore, a single residence time for recently recharged groundwater cannot be determined (Plummer et al. 2006). The use of CFCs as a tracer to estimate the time of recharge in the future will be limited or even become obsolete, depending on the rate of decline (Darling et al. 2012). $\mathrm{SF}_{6} \mathrm{~S}$ on the other hand, can provide unique recharge times due to its increasing atmospheric concentrations. Additionally, the records of initial concentrations of EWTs are limited worldwide in terms of period and geographical location. The use of multiple EWTs with different ranges of traceable periods will help overcome these limitations.

\section{Advanced EWTs}

Advanced EWTs group includes radioisotopes that can be naturally found in water and are commonly used for residence time estimations. Radiocarbon $\left({ }^{14} \mathrm{C}\right)$, with a halflife of 5730 years, is produced in the upper atmosphere via cosmic reactions (Clark and Fritz 1997). In addition to archaeological dating, it is used to estimate residence times of groundwater that is less than $\approx 45,000$ years old (Han and Plummer 2016). Atmospheric ${ }^{14} \mathrm{C}$ enters the groundwater as dissolved carbon dioxide $\left(\mathrm{CO}_{2}\right.$; inorganic carbon), which later exchanges with soil gas $\mathrm{CO}_{2}$ produced by organic matter oxidation in the soil zone. Measurements of ${ }^{14} \mathrm{C}$ are commonly made on DIC rather than DOC of the groundwater because it is more commonly present and easier to extract in the laboratory.

Tritium $\left({ }^{3} \mathrm{H}\right)$ is naturally produced in the upper atmosphere by cosmic reactions. ${ }^{3} \mathrm{H}$ is a part of the water molecule and is considered to be a direct water dating tool (Clark and Fritz 1997). Therefore, unlike ${ }^{14} \mathrm{C}$, the ${ }^{3} \mathrm{H}$ concentrations in a water sample are not altered by geochemical or biogeochemical reactions (Cartwright et al. 2017). Since ${ }^{3} \mathrm{H}$ has a relatively short half-life of 12.43 years, it can be used to date waters up to $\approx 60$ years old. The limitations caused by the increase and decrease of ${ }^{3} \mathrm{H}$ in precipitation since nuclear weapon testing in 1950s can be overcome using time series data.

Among the advanced EWTs, Radon $\left(\mathrm{Rn}^{222}\right)$ has the shortest half-life (3.8 days) and is found in the subsurface due to the radioactive decay of uranium isotopes (Cook et al. 2003). $\mathrm{Rn}^{222}$ is produced in deep underground bedrock and degasses at the surface; therefore, groundwater can have much higher concentrations than surface water. This principle is widely used to identify and quantify the discharge of groundwater into surface water or surface water recharge into aquifers and estimate residence times of river water in shallow aquifers (Baskaran et al. 2009; Cook et al. 2003; Stellato et al. 2013). It can be measured using in-situ portable equipment or within the laboratory.

The advanced EWT with the longest half-life $\left(3.01 \times 10^{5}\right.$ years), Chlorine- $36\left({ }^{36} \mathrm{Cl}\right)$, can be used to date 
groundwater ranging from hundreds of thousand years to up to a million years (Davis et al. 1998; Phillips 2013). ${ }^{36} \mathrm{Cl}$ originates in the upper atmosphere through natural processes, but like ${ }^{14} \mathrm{C}$ and ${ }^{3} \mathrm{H}$, it experienced elevated concentrations in the 1960s due to nuclear weapons testing (Cresswell 2004; Phillips 2013). Although it is considered a conservative tracer that is not affected by adsorption or other geochemical reactions, the addition of subsurface chloride and dead chloride (old, non-radioactive chloride) can occur during recharge and groundwater flow. These inputs need to be accounted for when estimating groundwater residence times using ${ }^{36} \mathrm{Cl}$ (Davis et al. 1998; Phillips 2013).

The radioisotopes of noble gases such as $\mathrm{Kr}, \mathrm{Ar}$, and $\mathrm{He}$ can be used to determine a wide range of groundwater residence times. ${ }^{85} \mathrm{Kr},{ }^{4} \mathrm{He},{ }^{39} \mathrm{Ar}$, and ${ }^{81} \mathrm{Kr}$ can be used to estimate residence times of $1-50$ years, $1-100$ years, $50-1000$ years, and 10,000-1,000,000 years, respectively (Cartwright et al. 2017). The use of these isotopes to calculate groundwater residence times is not common due to the high costs and difficulties of sampling and analysis. Although advances in analytical methods have reduced the sample volumes needed and analysis times (Du et al. 2003; Ritterbusch et al. 2014), the availability of instruments that measure these isotopes is not yet widespread, and the high costs of analysis still limit their application.

\section{Tracer Applications in the Mining Industry}

EWTs have been applied at mining sites throughout the world for understanding groundwater in resource commodities, including coal, iron ore, uranium, and metals. Specifically, when EWTs are used in a risk assessment framework within the mining industry, they can be used to address critical information gaps such as baseline hydrological conditions, hydraulic connections, and groundwater dependence of connected water assets. EWTs can improve the evaluation of the magnitude, duration, and frequency of effects and impacts of mining (Office of Water Science 2020). Tables 1 and 2 summarize case studies that have used EWTs in the mining industry to understand SW-GW interactions and inter-aquifer connectivity. The opportunities and limitations of the EWTs will be reviewed below for several common mine water and hydrogeological issues. It is essential to sample water flowing through aquifers (unlike stagnant water in boreholes) and to sample potential endmembers repeatedly to ensure spatial representativeness, and to sample water from backfill to evaluate effects on mixing ratios, as explained by Gu et al. (2017).
Table 1 Summary of case studies on EWT applications in the mining industry to assess hydraulic connectivity (Peerreviewed)

\begin{tabular}{|c|c|c|c|}
\hline Type of Mine & Location & EWTs used & Reference \\
\hline Coal - Underground & China & $\begin{array}{l}\text { Major ions } \\
\text { Stable isotopes }\end{array}$ & Huang et al. (2017) \\
\hline Coal and Gold-Underground & South Africa & $\begin{array}{l}\text { Major ions } \\
\text { Stable isotopes }\end{array}$ & Vermeulen et al. (2014) \\
\hline Iron-Open pit & Australia & $\begin{array}{l}\text { Major ions } \\
\text { Stable isotopes }\end{array}$ & Dogramaci et al. (2012) \\
\hline Coal-Underground & Australia & Stable isotopes & $\begin{array}{l}\text { David et al. (2018a) and } \\
\text { David et al. (2018b) }\end{array}$ \\
\hline Gold-Underground & China & $\begin{array}{l}\text { Major ions } \\
\text { Stable isotopes }\end{array}$ & Gu et al. (2017) \\
\hline Coal-Underground & China & $\begin{array}{l}\text { Water quality parameters } \\
\text { Major ions }\end{array}$ & Qian et al. (2017) \\
\hline Iron-Open Pit & Australia & $\begin{array}{l}\text { Radioisotopes }-{ }^{14} \mathrm{C},{ }^{3} \mathrm{H} \\
\text { Dissolved gases }-\mathrm{CFC}, \mathrm{SF}_{6} \\
\text { Noble gases }-{ }^{85} \mathrm{Kr},{ }^{39} \mathrm{Ar}\end{array}$ & McCallum et al. (2017) \\
\hline Coal-Underground & China & $\begin{array}{l}\text { Major ions } \\
\text { Stable isotopes }\end{array}$ & Guo et al. (2019) \\
\hline Coal-Open Pit & India & Stable isotopes & Dhakate et al. (2018) \\
\hline Iron-Open Pit & Australia & $\begin{array}{l}\text { Radioisotopes }-{ }^{36} \mathrm{Cl},{ }^{14} \mathrm{C},{ }^{3} \mathrm{H} \\
\text { Dissolved gases }-\mathrm{CFC} \text { and } \mathrm{SF}_{6}\end{array}$ & Cook et al. (2016) \\
\hline Coal & Australia & $\begin{array}{l}\text { Radioisotopes }-{ }^{222} \mathrm{Rn} \\
\text { Noble gases }-{ }^{4} \mathrm{He}\end{array}$ & Gardner et al. (2011) \\
\hline Coal-Underground & Australia & Major ions & Imrie (2019) \\
\hline Copper-Open pit & Iran & $\begin{array}{l}\text { Stable isotopes } \\
\text { Radioactive isotopes }-{ }^{3} \mathrm{H}\end{array}$ & Parizi and Samani (2014) \\
\hline Uranium-Open pit & India & Major ions & Manoj et al. (2019) \\
\hline
\end{tabular}


Table 2 Industry reports of Australian mines currently using EWTs in Conceptualization and Component tracing (non-peer reviewed)

\begin{tabular}{lll}
\hline Type of Mine & EWTs used & Reference \\
\hline Iron-Open Pit & Water quality parameters, major ions & Russo (2019) \\
Australia & Stable isotopes & Arup Pty et al. (2009) \\
Copper-Open pit & Water quality parameters, major ions & HydroSimulations (2019) \\
Australia & Radioisotope $-{ }^{36} \mathrm{Cl}$ & \\
Coal-Underground & Water quality parameters, major ions, & Leaney and Puhalovich (2006) \\
Australia & Trace elements, radioisotopes $-{ }^{3} \mathrm{H}$ & \\
Uranium-Underground & Investigations on ${ }^{14} \mathrm{C},{ }^{36} \mathrm{Cl},{ }^{7} \mathrm{Li} /{ }^{6} \mathrm{Li}$, and ${ }^{87} \mathrm{Sr} /{ }^{86} \mathrm{Sr}$ tracers are underway & Central Queensland Coal (2020) \\
Australia & Water quality parameters, major ions, stable isotopes, dissolved gases - & \\
Coal-Open Pit & $\mathrm{CFC}$, radioisotopes $-{ }^{14} \mathrm{C},{ }^{222} \mathrm{Rn}$ & \\
Australia & Water quality parameters, nutrients, and major ions, metals and metalloids, & \\
\hline
\end{tabular}

\section{Identifying Water Sources (Endmembers) and Mixing}

EWTs can be used to identify mixing patterns between mine water, surface water, and groundwater. Mixing ratios can be calculated for each endmember in a given mixing scenario. The $\delta^{18} \mathrm{O}$ and $\delta^{2} \mathrm{H}$ signatures of a water sample, when coupled with other primary EWTs, can be used to identify sources of water in SW-GW samples. For example, possible sources of inrush to a coal mine was identified using hydrochemical facies, correlations of ionic ratio $(\mathrm{Ca} / \mathrm{Na}$ and $\mathrm{Mg} /$ $\mathrm{Na}$ ratios, $\mathrm{Ca}+\mathrm{Mg}) / \mathrm{HCO}_{3}$ vs. $\mathrm{SO}_{4}{ }_{4} \mathrm{HCO}_{3}$ ), and stable isotopes $\left(\delta^{18} \mathrm{O}, \delta^{2} \mathrm{H}, \mathrm{SO}_{4}\right.$, and $\left.{ }^{34} \mathrm{~S}\right)$ in China (Huang et al. 2017). Vermeulen et al. (2014) showed how key primary EWTs can be used to distinguish groundwaters with similar origins and their evolution near two underground coal and gold mines in South Africa. Their study traced the water sources dripping from the roof of the mine and the overlying aquifers. Additionally, the locations of fractures, faults, and inter-aquifer connections were identified based on the primary EWTs. These findings contributed to the risk assessment of potential aquifer contamination due to mine drainage from the mining. Another example of a risk assessment that included information from EWTs was provided by Dogramaci et al. (2012) and Russo (2019) for an arid zone catchment with mining operations in Australia. They estimated the proportion of surface water and rainwater present in surface water pools and shallow groundwater using primary EWTs. Their findings suggested that groundwater recharge mainly occurred during large-scale episodic rainfall events and that some of the pools were groundwater fed.

At an underground coal mine in Australia, David et al. (2018a, b) demonstrated the use of analysing stable isotopes in pore water to identify groundwater as the dominant endmember of a wetland during the dry season. Prior to using EWTs, the limited information on the groundwater system had suggested that rainwater and run-off recharge were the dominant sources of water to the wetlands. In addition to delineating the origin of groundwater from rainfall, rivers, and aquifers, isotopic signatures also help delineate the presence of paleowater, which is considered to be a nonrenewable resource and recharged on the hundred thousand to million-year timescale (Plummer et al. 2013). For example, Arup Pty et al. (2009) used ${ }^{36} \mathrm{Cl}$ in addition to major ions to assess possible interactions between the paleogroundwater contained in the Great Artesian Basin (GAB) and groundwater from the local aquifer close to the copper mine. This tracer indicated no interaction. However, considering the risk of affecting GAB springs and other groundwater dependent ecosystems (GDE) of GAB, other EWTs could be used to confirm groundwater mixing and interactions.

The value of collecting a time series of suitable EWT over different areas of a mine was demonstrated with a comprehensive data set consisting of 70 groundwater samples and 242 surface water samples of ${ }^{3} \mathrm{H}$ data in an underground coal mine study in the southern Sydney coal basin (HydroSimulations 2019). Mixing percentages of young water (50-70 years) in seepage samples were estimated using these time series data. Simple linear mixing models used to evaluate the mixing fractions indicated that modern water (i.e. containing ${ }^{3} \mathrm{H}$ ) had gradually moved through hundreds of meters of rock strata to a coal seam dominated by premodern water.

Primary EWTs have been used to reveal a change in endmember mixing patterns in a fractured groundwater system located above a coastal underground mine in China (Gu et al. 2017). In this case, primary EWTs showed that the proportion of brine in shallow fractured aquifers decreased over 20 years of mining. Artificial drainage during mining and infiltration of Quaternary and seawater through the bedrock fractures due to a high hydraulic gradient have changed the water sources and mixing ratios. This example shows the role of primary EWTs as a systematic monitoring method to trace such mixing patterns, artificial drainage, and increased infiltration due to mining-induced fractures throughout the mine life cycle. Alternatively, sources of recharge to surface 
water can be identified using advanced EWTs such as ${ }^{222} \mathrm{Rn}$, which typically occurs at low concentrations in surface water due to diffusion and decay (Leaney and Puhalovich 2006). Their study recommended an integrated approach in using water balancing, salinity, and stable isotopic composition to identify possible seasonal groundwater input to a billabong near a uranium mine in Australia based on multiple sampling campaigns to capture seasonal variations. Similar temporal changes of SW-GW interactions were identified by integrating groundwater level fluctuations, geological data, and uranium speciation and saturation indices in water at a uranium mine in India by Manoj et al. (2019).

Distinguishing endmembers at mine sites where water is reused or recycled can be difficult using only primary EWTs. Reused or recycled water (even after treatment) may contain similar ionic tracer compositions and isotopic tracer signatures as groundwater. In such cases, an alternative approach that uses EWTs that undergo re-equilibration with the atmosphere after entering surface water can be very useful. Cook and Dogramaci (2019) used CFC-12, ${ }^{14} \mathrm{C}$, and ${ }^{3} \mathrm{H}$ (decreasing order of re-equilibration rates) to distinguish four endmembers, including recycled surface water, at an iron ore mine in Australia. The different re-equilibration rates provide additional information when trying to distinguish multiple endmembers (Bourke et al. 2015). Similarly, dissolved gases such as $\mathrm{SF}_{6}$ and ${ }^{4} \mathrm{He}$ might be suitable (Busenberg and Plummer 2000). An advantage of using dissolved gas tracers for distinguishing between endmembers is that they equilibrate upon contact with the atmosphere, unlike ionic and stable isotopic EWTs. Advanced statistical approaches have been used on major ion chemistry datasets to identify connections between fractured aquifers overcoming such uncertainties (Qian et al. 2017).

\section{Identifying Vulnerable Surface and Groundwater Resources Using Residence Times Estimations}

The residence time of a water sample is the period since it was recharged (Cartwright et al. 2020). Residence time estimations can be used as a guide for recharge, and aquifers with longer residence times may be considered more vulnerable to over-extraction. The percentage of modern water present in a mine can be estimated using residence times derived from ${ }^{3} \mathrm{H}$ (HydroSimulations 2019). However, it should be noted that there is a risk of bias in calculated residence time estimates compared to the actual residence times found in a mixture of water due to many factors. Molecules in a water sample follow different flow paths with different travel times, and each water sample will therefore have a distribution of residence times, especially when samples are withdrawn from long screen intervals in wells (McCallum et al. 2015). Therefore, it is suggested that multiple residence time tracers be used to reduce the uncertainty associated with using one tracer method. McCallum et al. (2017) used $\mathrm{CFCs}, \mathrm{SF}_{6},{ }^{3} \mathrm{H}$, and ${ }^{14} \mathrm{C}$ to delineate modern and historic recharge events of the groundwater system near an iron ore mine in Australia. Groundwaters were found to be composed of four endmembers with residence times less than 20 years, 50-200 years, 100-600 years, and 1000-2000 years.

Suckow et al. (2019) found that the difference in ${ }^{14} \mathrm{C}$ and ${ }^{3} \mathrm{H}$ results can be explained by the dual porosity in fractured aquifer systems. These studies show that a variety of hydrogeological and hydrogeochemical methods are needed to understand how residence time indicators behave in a groundwater system. Further detailed discussions of various residence time indicators are found in the literature (Cartwright et al. 2017; Cook et al. 2006; Meredith et al. 2016; Plummer and Glynn 2013; Suckow et al. 2019).

\section{Determination of the Spatial Extent of Mining Effects and Impacts}

Constraining the spatial extent of the impacts of mining in terms of hydraulic connections is vital for water resource management. The hydraulic connections due to mineinduced fissures at the surface can be evidenced by the higher proportion of river water than rainfall in groundwater recharge. A study by Guo et al. (2019) in China, found that the proportion of recharge from a nearby river was greater than $50 \%$ within $5.5 \mathrm{~km}$ of the river course using investigation EWTs and simple mixing models. Further, the attributes of buffer zones and requirements for barriers can be validated by studying groundwater-river interactions using EWTs (Dhakate et al. 2018). Thus, EWTs can be employed for the independent verification of groundwater flow model predictions.

Ideally, EWTs are part of investigations that characterize small-scale heterogeneities, relative hydraulic conductivities, transport mechanisms (i.e. advection and diffusion), and flow directions more precisely than the numerical groundwater flow models. This in turn produces better evaluations of the spatial extent of mining impacts. For example, David et al. (2015) shows how investigation EWTs were used to confirm hydrogeologic zones in heterogeneous sedimentary strata in the southern coalfield of the Sydney Basin. The importance of thin clay rich and iron-stained rocks in controlling vertical and horizontal flow was revealed in this study of $\delta^{18} \mathrm{O}$ and $\delta^{2} \mathrm{H}$ isotopes in pore water. Both investigation and advanced EWTs were used by Cook et al. (2016) to identify spatial variation in mixing young and old water. The ${ }^{3} \mathrm{H}$ activity, ${ }^{14} \mathrm{C}$ content, and $\mathrm{CFC}-12$ concentrations decreased with depth and increased towards a creek, revealing the drawdown of young water from shallow aquifers. Increased ${ }^{14} \mathrm{C}$ content and $\mathrm{Cl}$ depicted a gradual increase in the fraction of the creek recharge in pumped groundwater, showing 
the degree of impact due to pumping spatially. This shows how different types of EWTs can provide detailed insights for precise impact assessment.

\section{Estimating Flow Velocities, Recharge Rates, and Base Flow}

Residence times derived from EWTs can be used to determine groundwater flow velocities and recharge rates (Cartwright et al. 2017; Pearson Jr and White 1967; Suckow 2013; Suckow et al. 2019). Independently determined flow velocities are useful for validating the calculated flow velocities estimated using traditional hydraulic methods with uncertain hydraulic parameters (Cook and Böhlke 2000). For example, Gardner et al. (2011) used ${ }^{222} \mathrm{Rn}$ and ${ }^{4} \mathrm{He}$ to identify groundwater discharge areas and the proportions of local or regional groundwater in discharge in the Canning Basin in Australia that had undergone mineral extraction and coal mining for the past 10 to 20 years. Based on the EWT results, proponents of a mining project were able to demonstrate that one of the nearby creeks was not hydraulically connected with groundwater and was not at risk from mining effects (Central Queensland Coal 2020). In contrast, in another study area, a creek was found to have relatively high ${ }^{222}$ Rn levels, indicating groundwater discharge and the risk of potential impact from groundwater drawdown from an open pit.

Significant changes to the baseflow of rivers can be estimated with hydrogeological data and flow measurements, and validated using stable isotopes. Dhakate et al. (2018) used this approach to evaluate the proportion of base flow received from a specific coal aquifer that had been subjected to pumping. The loss of recharge from the coal aquifer was considered insignificant based on the total groundwater discharge received by the river. Furthermore, EWTs can be used to characterise the discharge mine water for monitoring and water management purpose. Imrie (2019) characterized the two dominant hydrogeological systems contributing to the river base flow, Triassic discharge, and treated mine water discharges. The treated mine water resulted in high $\mathrm{SO}_{4}$ concentrations, despite the approved salinity levels of the discharge. Regulatory limits on salinity without regard to chemistry is a loophole that can affect the ecology of the river. Opitz and Timms (2016) reviewed various frameworks for classifying mine water discharge through the applications of EWTs. They found that most frameworks are only based on specific EWTs, such as $\mathrm{pH}$, metals, and $\mathrm{SO}_{4}$ indicative of acid and metalliferous mine drainage. There are often opportunities to use a suite of primary EWTs that can help monitor the quality of discharge waters.

\section{Limitations in Terms of Cost, Turn-Around Time, and Expertise}

The various EWTs analyses need to be affordable and have timely turn-around times for them to be integral in the decision-making process in a mining project. A full suite of major and minor elemental chemistry and isotopic analyses generally costs less than 100 USD per sample. Although analytical facilities for elemental chemistry are, for the most part, readily available, not all laboratories have the advanced equipment and facilities to analyse isotopes. Stable isotope analyses may cost between 10 and 100 USD, per sample, depending on the laboratory. The analytical costs for dissolved gases ( $\left.\mathrm{CFCs}, \mathrm{SF}_{6}\right)$ and radioisotopes $\left({ }^{3} \mathrm{H},{ }^{14} \mathrm{C},{ }^{36} \mathrm{Cl}\right)$ are on the order of approximately 200 USD and 700 USD per sample, respectively. The turnaround time for reporting results depends on the difficulty of pre-treatment, the complexity of the analytical method, and the laboratory facility where the samples are analysed. Primary EWTs can be analysed in-situ and in the laboratory faster than investigation and advanced EWTs. Since there are only a limited number of laboratories capable of conducting investigation and advanced EWT analysis, longer turn-around times can generally be expected. As a result, the use of EWTs may be infeasible at sites with budgetary, logistical, and time constraints. For example, using advanced EWTs may not provide results fast enough at instances where an urgent response is required to constrain a hydrogeological problem. Application of EWTs can be optimized under a proactive approach towards hydrogeological monitoring of the mine.

Additionally, it is important that the samples (except for dissolved gases) be collected in clean, high-density polyethylene (HDPE) bottles and are well preserved (cations and metals) to minimize water chemistry changes between collection and analysis. $\mathrm{CFC}$ and $\mathrm{SF}_{6}$ samples are collected in transparent and amber glass bottles, respectively. Some preservation methods, such as freezing, are critical for advanced EWTs such as ${ }^{14} \mathrm{C}_{\text {DOC }}$. Cartwright et al. (2017) summarise the use and limitations of the radioisotopes and residence time tracers based on their sampling methods, costs, analytical methods, and ancillary information requirements before sampling. Figure 2 summarises a broader range of EWTs based on relative costs, effort, and processing times.

The reliability of the EWT results depends on the sampling methods employed in the field and the laboratory methods used. Interpretation of results rely on a variety of modelling and interpretation techniques, as described above. EWTs may change in the unsaturated and saturated zones during and after recharge via physical processes (e.g. diffusion, dispersion, adsorption), chemical 


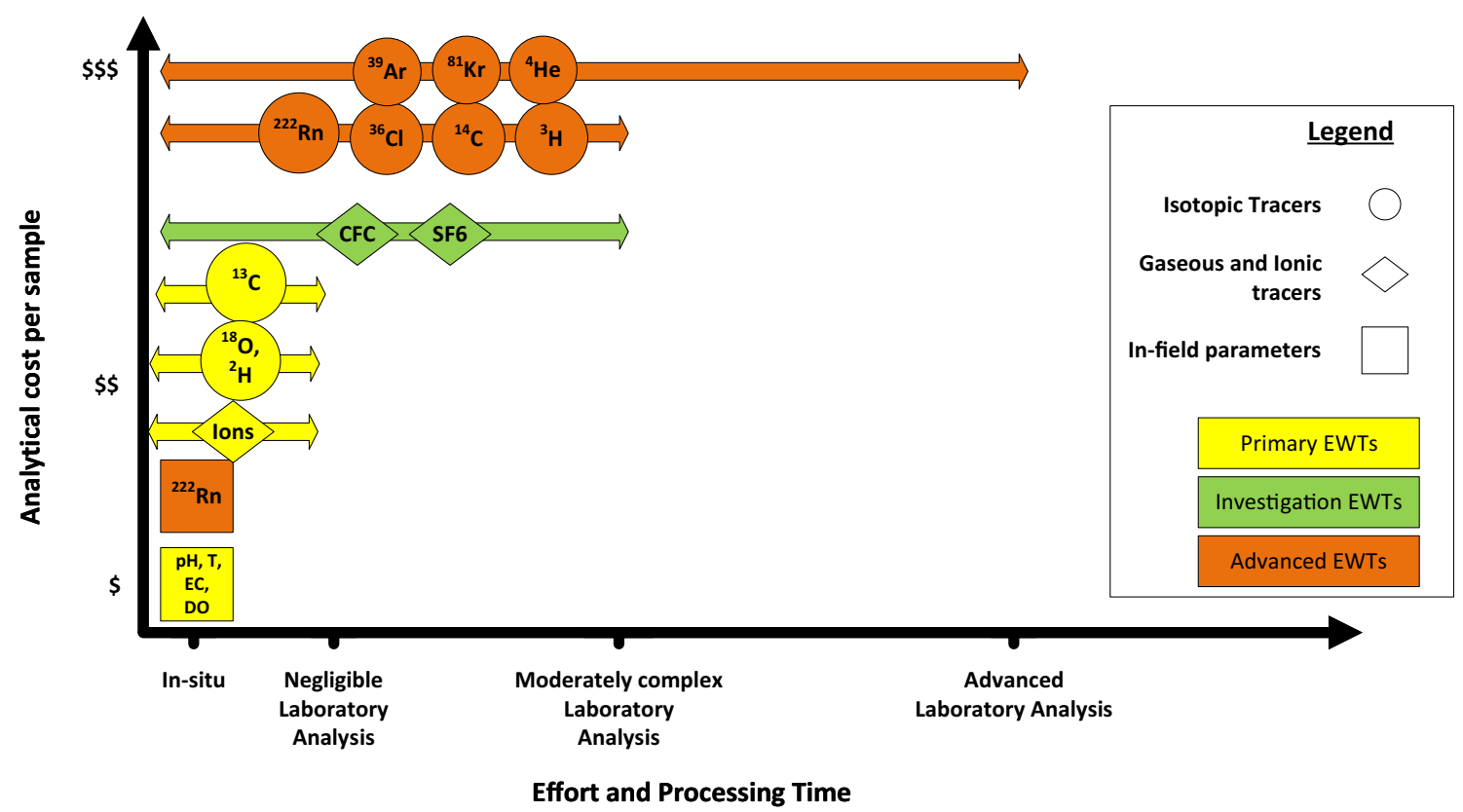

Fig. 2 A qualitative interpretation of relative analytical costs, effort and processing time for primary, investigation and advanced EWTs

processes (e.g. dissolution, oxidation, ion exchange, and isotope exchange), and biological processes (e.g. oxidation, digestion, biomineralization) (Appelo and Postma 2004). The contribution of carbon after recharge can lead to overestimation of groundwater residence times (Han and Plummer 2016). However, geochemical modelling approaches using PHREEQC and NETPATH can be used to correct EWT concentrations for certain chemical processes (Plummer and Glynn 1992). Dissolved gases typically show conservative behaviour in groundwater systems (Chambers et al. 2019). Cook et al. (2006) and Darling et al. (2012) discuss the practicalities in their applications and the interferences that can alter the recharge time estimations. For example, high CFC concentrations have been associated with contamination from underground storage tanks, sewer lines, industrial waste, or sampling error.

Furthermore, input parameters such as recharge temperature, elevation, and salinity, are factored in residence time estimation. Table 3 summarises the factors and model input parameters that can alter EWT results.

It is imperative to consider all of the EWT sources and sinks, and to use accurate local input parameters to avoid any misinterpretation of data. For example, not having local historical EWT variations in precipitation can cause high uncertainties in data interpretation. Overall, sampling water for advanced EWTs and interpretation of EWTs data demands training and expertise in EWTs. This incurs further expenses, which may be considered a limiting factor for EWT application where there are constraints in budgets and available expertise.
A conceptual diagram (Fig. 3, adapted from Suckow (2014) and Cartwright et al. (2017)) outlines the residence time tracers discussed in this paper and summarizes the different attributes relative to each other. The uncertainty behind the interpretations of non-conservative EWTs without following the appropriate control or corrective measures are conceptually indicated in Fig. 3. Having combined the analysis of ratios of EWTs or time series data and other corrective measures stated in Table 3, all EWTs are considered equally useful in hydrogeological assessments. Therefore, based on this characterization, it is recommended that you select a suite of EWTs that represent a range of residence times, with different levels of non-conservativeness addressed, to optimize EWTs. Given the above prerequisites for advanced EWT applications, it is most practical to select EWTs that are commensurate with the associated risks.

\section{Selecting Suitable EWTs Commensurate with Risks}

Several factors should be considered in selecting the appropriate EWTs to take advantage of the growing opportunities of EWT applications in water studies for the mining industry. The following steps should be followed to support decisions for a specific mining project:

1. Identify the key mine water risks at the site to determine if EWTs could be helpful. For example, the possibility of large inflows to a mining void could be a 


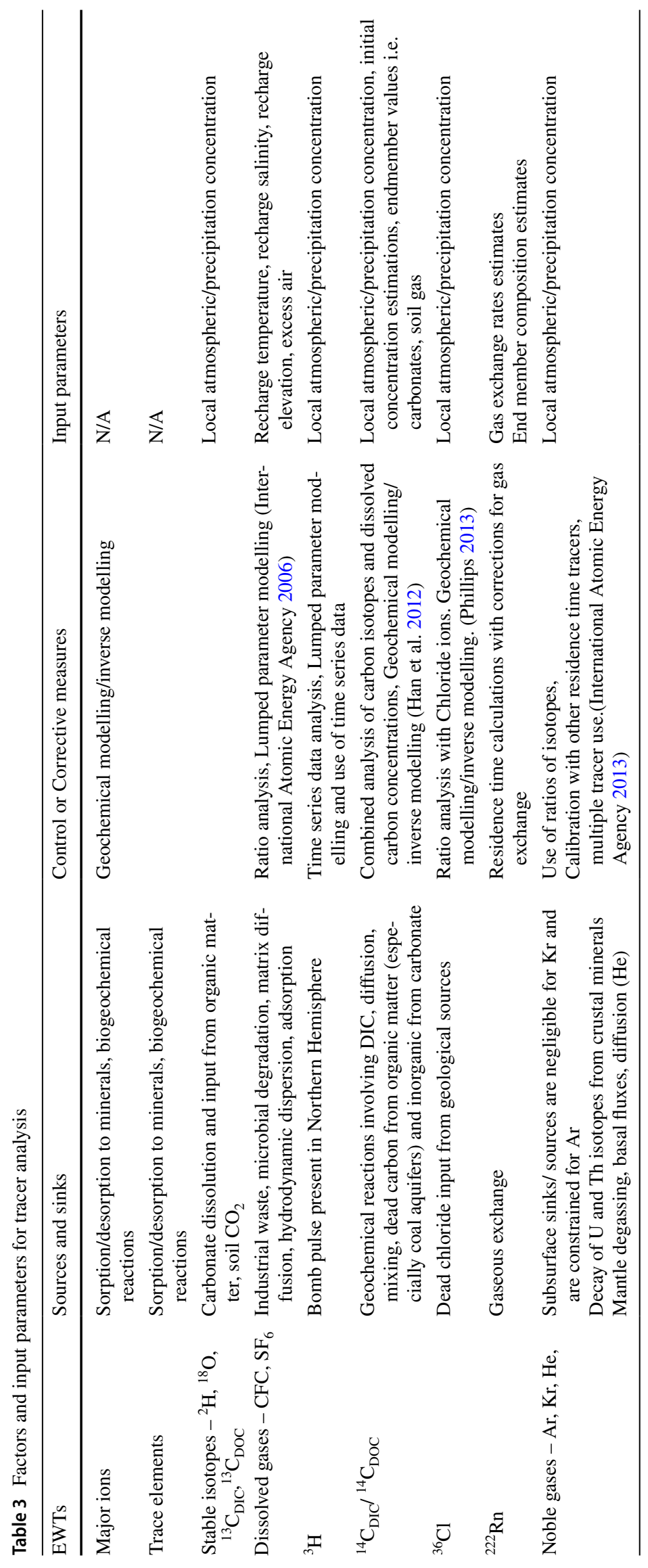




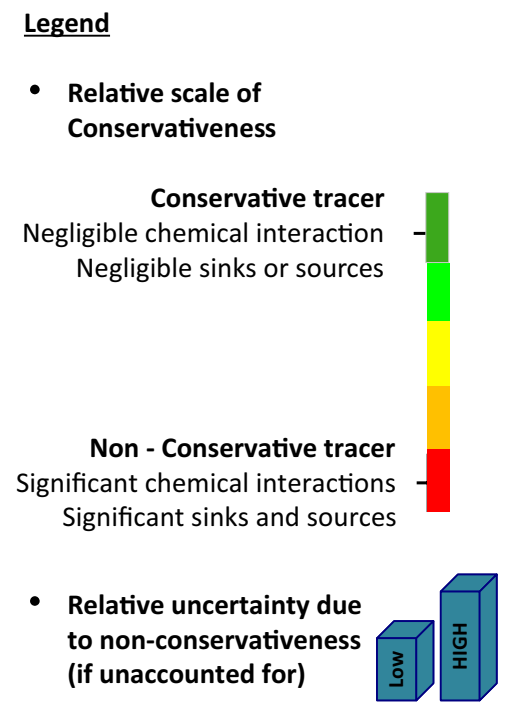

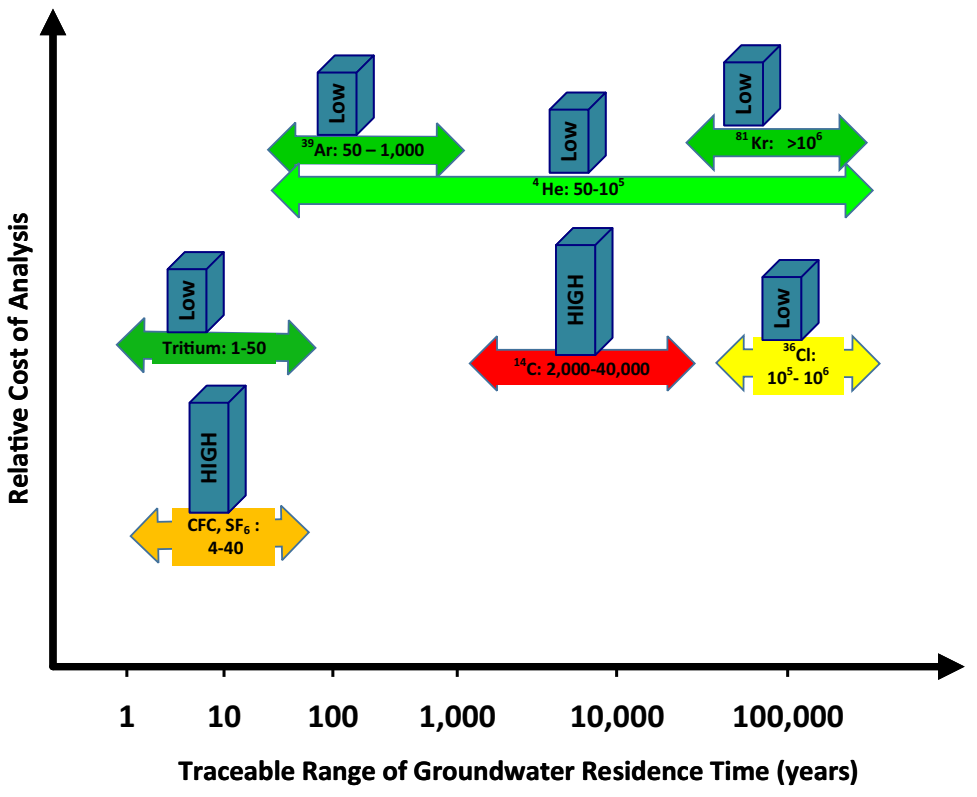

Fig. 3 Conceptual figure of factors to consider when choosing an EWT based on residence time range and the conservativeness. Modified from Suckow (2014) and Cartwright et al. (2017)

critical risk. Similarly, the potential for loss of water from a wetland, while not a risk for the mining operations, could threaten the environment and regulatory limits.

2. Select suitable EWTs commensurate with risks to the mining operation and environmental assets. For example, if water near a mine site poses a low or moderate risk to mining operations or interactions with the environment, then baseline EWTs or selecting some investigation EWTs would be most appropriate. Advanced tracer studies may be suitable where there is a high risk of an in-rush to the mining void or if water resources of high environmental value could potentially be impacted.

3. Identify how EWTs complement and can be used to validate other available hydrological information such as flow directions, water levels, flow velocities, and aquifer recharge rates derived from physical, hydraulic methods, and groundwater flow models.

4. Determine the associated costs and sampling requirements of the selected EWTs. For example, several tracers have specific preparation, sampling, and preservation methods that ensure the repeatability of studies and control quality in the EWT applications.

5. Design a sampling plan, including locations, sampling depths, and reference (non-mining) sample sites based on preliminary data such as geology, drill $\operatorname{logs}$, water levels, and anticipated risks.

6. Determine the suitable frequency of the sampling campaign.
7. Identify the distinctive endmembers or variations in water tracer concentrations or different geochemical processes taking place across different waters and aquifers at the site.

8. Understand the nature of the tracers (reactive or nonreactive) and processes altering tracer concentrations, such as geochemical interactions that may take place along the flow path, as well as decay. Make corrections to tracer concentrations taking these interferences into account before computing residence time estimates or other calculations.

9. Clearly understand the principles behind EWT models that are used, underlying assumptions, and additional information required to interpret EWT results.

10. Consider how water tracer data could contribute to mine water decisions and improve confidence in the modelling of surface water and groundwater systems.

In summary, EWTs provide an additional line of evidence to understand surface water-groundwater interactions, independent of hydraulic parameters and numerical models, given that each technique is subject to uncertainty. The opportunities include, but are not limited to, identification of sources of water (even minor proportions of relatively modern water present in mine seepage), and processes such as recharge, base flow, and flow velocity. The presence of vulnerable aquifers, or GDEs can be identified and the extent to which mining might affect them can be assessed using spatial variations of EWTs. 
The importance of selecting appropriate water tracers for specific mine site applications is clear from many of the case studies discussed in this paper. It is recommended that you select a suite of EWTs with a wide range of traceable residence times, while addressing non-conservative tracer characteristics. However, the costs of analysis and interpretation of advanced EWTs may be a limitation where there are constraints on time, budget, and expertise (both in terms of sampling/analysis techniques, and interpretation of results). Therefore, you should select suitable EWTs commensurate with the risks to mining operations and environmental and water assets.

Acknowledgements We gratefully acknowledge support by the Australian Coal Association Research Program (ACARP) grant C28024. We also thank the reviewers who helped improve the structure and content of this paper.

Funding Open Access funding enabled and organized by CAUL and its Member Institutions.

Open Access This article is licensed under a Creative Commons Attribution 4.0 International License, which permits use, sharing, adaptation, distribution and reproduction in any medium or format, as long as you give appropriate credit to the original author(s) and the source, provide a link to the Creative Commons licence, and indicate if changes were made. The images or other third party material in this article are included in the article's Creative Commons licence, unless indicated otherwise in a credit line to the material. If material is not included in the article's Creative Commons licence and your intended use is not permitted by statutory regulation or exceeds the permitted use, you will need to obtain permission directly from the copyright holder. To view a copy of this licence, visit http://creativecommons.org/licenses/by/4.0/.

\section{References}

Appelo CAJ, Postma D (2004) Geochemistry, groundwater and pollution. CRC Press, Boca Raton

Arup Pty Ltd., EAP, Billiton BHP (2009) Olympic Dam expansion: draft environmental impact statement. Prepared by Arup Pty Ltd and ENSR Australia Pty Ltd on behalf of BHP Billiton Olympic Dam Corp Pty Ltd. www.bhp.com/-/media/bhp/regulatory-infor mation-media/copper/olympic-dam/0000/draft-eis-main-report/ odxeisfrontpages.pdf

Banks EW, Green GP, Wilson TC (2008) Hydrogeochemical investigations of interactions between groundwater and surface water in a fractured rock environment, Mount Lofty Ranges, South Australia. Proc Water down under 2008:2149

Baskaran S, Ransley T, Brodie RS, Baker P (2009) Investigating groundwater-river interactions using environmental tracers. Aust J Earth Sci 56(1):13-19. https://doi.org/10.1080/0812009080 2541887

Booth CJ (2006) Groundwater as an environmental constraint of longwall coal mining. Environ Geol 49(6):796-803. https://doi.org/ 10.1007/s00254-006-0173-9

Bourke SA, Cook PG, Dogramaci S, Kipfer R (2015) Partitioning sources of recharge in environments with groundwater recirculation using carbon-14 and CFC-12. J Hydrol 525:418-428. https:// doi.org/10.1016/j.jhydrol.2015.03.061
Brodie R, Sundaram B, Tottenham R, Hostetler S, Ransley T (2007) An overview of tools for assessing groundwater-surface water connectivity. Bureau of Rural Sciences, Canberra

Busenberg E, Plummer LN (1992) Use of chlorofluorocarbons (CCl3F and $\mathrm{CCl} 2 \mathrm{~F} 2$ ) as hydrologic tracers and age-dating tools: the alluvium and terrace system of central Oklahoma. Water Resour Res 28(9):2257-2283

Busenberg E, Plummer LN (2000) Dating young groundwater with sulfur hexafluoride: natural and anthropogenic sources of sulfur hexafluoride. Water Resour Res 36(10):3011-3030. https://doi. org/10.1029/2000wr900151

Cartwright I, Cendón D, Currell M, Meredith K (2017) A review of radioactive isotopes and other residence time tracers in understanding groundwater recharge: possibilities, challenges, and limitations. J Hydrology 555:797-811. https://doi.org/10.1016/j. jhydrol.2017.10.053

Cartwright I, Currell MJ, Cendón DI, Meredith KT (2020) A review of the use of radiocarbon to estimate groundwater residence times in semi-arid and arid areas. J Hydrology. https://doi.org/10.1016/j. jhydrol.2019.124247

Central Queensland Coal (2020) Central Queensland coal projectsupplementary environmental impact statement. Appendix A10H-Preliminary isotope study, version 3. https://cqcoal.com. au/wp-content/uploads/2020/10/Appendix-10h-Preliminary-Isoto pe-Study-Results.pdf

Chambers LA, Gooddy DC, Binley AM (2019) Use and application of CFC-11, CFC-12, CFC-113 and SF6 as environmental tracers of groundwater residence time: a review. Geosci Front 10(5):16431652. https://doi.org/10.1016/j.gsf.2018.02.017

Clark I, Fritz P (1997) The environmental isotopes. Environmental Isotopes in Hydrogeology:2-34

Cook PG, Böhlke J-K (2000) Determining timescales for groundwater flow and solute transport. environmental tracers in subsurface hydrology. p 1-30. https://doi.org/10.1007/978-1-4615-4557-6_1

Cook P, Dogramaci S (2019) Estimating recharge from recirculated groundwater with dissolved gases: an end-member mixing analysis. Water Resour Res 55(7):5468-5486

Cook PG, Favreau G, Dighton JC, Tickell S (2003) Determining natural groundwater influx to a tropical river using radon, chlorofluorocarbons and ionic environmental tracers. J Hydrol 277(1-2):74-88. https://doi.org/10.1016/s0022-1694(03)00087-8

Cook P, Plummer L, Busenberg E, Solomon D, Han L (2006) Effects and processes that can modify apparent CFC age. Use of Chlorofluorocarbons in Hydrology: a Guidebook, International Atomic Energy Agency: 31-58

Cook P, Dogramaci S, McCallum J, Hedley J (2016) Groundwater age, mixing and flow rates in the vicinity of large open pit mines, Pilbara region, northwestern Australia. Hydrogeol J 25(1):39-53. https://doi.org/10.1007/s10040-016-1467-y

Craig H (1961) Isotopic variations in meteoric waters. Science 133(3465):1702-1703. https://doi.org/10.1126/science.133.3465. 1702

Cresswell RG (2004) Chlorine-36 analysis of pore fluids from diamond cores from the Lower Balonne area, southern Queensland, Australia. Bureau of Rural Sciences

Darling WG, Gooddy DC, MacDonald AM, Morris BL (2012) The practicalities of using CFCs and SF6 for groundwater dating and tracing. J Appl Geochem 27(9):1688-1697. https://doi.org/10. 1016/j.apgeochem.2012.02.005

David K, Timms W, Baker A (2015) Direct stable isotope porewater equilibration and identification of groundwater processes in heterogeneous sedimentary rock. Sci Total Environ 538:1010-1023. https://doi.org/10.1016/j.scitotenv.2015.08.075

David K, Timms W, Baker A, McGeeney D (2018a) Hydrogeochemical characterisation of swamps near underground mining 
development. 11th ICARD/IMWA/MWD Conference 2018: Risk to Opportunity

David K, Timms W, Hughes C, Crawford J, McGeeney D (2018b) Application of the pore water stable isotope method and hydrogeological approaches to characterise a wetland system. Hydrol Earth Syst Sci 22:6023-6041. https://doi.org/10.5194/ hess-22-6023-2018

Davis SN, Cecil D, Zreda M, Sharma P (1998) Chlorine-36 and the initial value problem. Hydrogeology J 6(1):104-114

Dhakate R, Modi D, Rao VVSG (2018) Impact assessment of coal mining on river water and groundwater and its interaction through hydrological, isotopic characteristics, and simulation flow modeling. Arab J Geosci. https://doi.org/10.1007/s12517-018-4110-5

Dogramaci S, Skrzypek G, Dodson W, Grierson PF (2012) Stable isotope and hydrochemical evolution of groundwater in the semiarid Hamersley Basin of subtropical northwest Australia. J Hydrol 475:281-293. https://doi.org/10.1016/j.jhydrol.2012.10.004

Du X, Purtschert R, Bailey K, Lehmann BE, Lorenzo R, Lu ZT, Mueller P, O'Connor TP, Sturchio NC, Young L (2003) A new method of measuring $81 \mathrm{Kr}$ and $85 \mathrm{Kr}$ abundances in environmental samples. Geophys Res Lett. https://doi.org/10.1029/ 2003 gl018293

Evans GV (1983) Tracer techniques in hydrology. Int JAppl Radiat Isot 34(1):451-475. https://doi.org/10.1016/0020-708X(83) 90144-8

Fetter C (1994) Applied hydrogeology

Gardner WP, Harrington GA, Solomon DK, Cook PG (2011) Using terrigenic $4 \mathrm{He}$ to identify and quantify regional groundwater discharge to streams. Water Resour Res. https://doi.org/10.1029/ 2010WR010276

Gibbs RJ (1970) Mechanisms controlling world water chemistry. Science 170(3962):1088-1090. https://doi.org/10.1126/science.170. 3962.1088

Gu H, Ma F, Guo J, Li K, Lu R (2017) Assessment of Water sources and mixing of groundwater in a coastal mine: the Sanshandao gold mine. China Mine Water Environ 37(2):351-365. https://doi.org/ 10.1007/s10230-017-0458-0

Guo Q, Yang Y, Han Y, Li J, Wang X (2019) Assessment of surfacegroundwater interactions using hydrochemical and isotopic techniques in a coalmine watershed, NW China. Environ Earth Sci. https://doi.org/10.1007/s12665-019-8053-2

Han LF, Plummer LN (2016) A review of single-sample-based models and other approaches for radiocarbon dating of dissolved inorganic carbon in groundwater. Earth-Sci Rev 152:119-142. https:// doi.org/10.1016/j.earscirev.2015.11.004

Han L-F, Plummer LN, Aggarwal P (2012) A graphical method to evaluate predominant geochemical processes occurring in groundwater systems for radiocarbon dating. Chem Geol 318-319:88-112. https://doi.org/10.1016/j.chemgeo.2012.05.004

Huang X, Wang G, Liang X, Cui L, Ma L, Xu Q (2017) Hydrochemical and stable isotope ( $\delta \mathrm{D}$ and $\delta 18 \mathrm{O}$ ) characteristics of groundwater and hydrogeochemical processes in the Ningtiaota coalfield, northwest China. Mine Water Environ 37(1):119-136. https://doi. org/10.1007/s10230-017-0477-x

HydroSimulations (2019) Dendrobium Mine - Plan for the Future: Coal for Steelmaking - Groundwater Assessment. Report for South32 - Illawarra Coal Dendrobium Mine, NSW, Australia

Imrie J (2019) Changing land use in an uncertain climate: Impacts on Surface water and Groundwater in the Goulburn River, NSW. PhD Diss, Australian National University

International Atomic Energy Agency (2006) Use of chlorofluorocarbons in hydrology: A Guidebook. Internat. Atomic Energy Agency

International Atomic Energy Agency (2013) Isotope methods for dating old groundwater. International Atomic Energy Agency
International Atomic Energy Agency (2016) Technical Meeting on the Use of Isotopes for Characterizing the Source and Transport of Pollutants in Groundwater and Surface Water in Relation to Hydraulic Fracturing and Mining Operations IAEA Headquarters, Vienna, AUSTRIA Meeting Room: C0343

Jankowski J, Knights P (2010) Surface water-groundwater interaction in the fractured sandstone aquifer impacted by mining-induced subsidence: 1. Hydrology and hydrogeology. Biul Państw Inst Geol Hydrogeol Biuletyn Panstwowego 441:33-42

Lamontagne S, Mallants D (2018) Workshop on Environmental Tracers in Coal and Unconventional Gas Development Proposals, Summary Report

Leaney FW, Puhalovich AA (2006) Use of environmental tracers to better understand groundwater recharge/discharge processes, Ranger Uranium Mine, NT. Report for ERA Ltd(CSIRO Land and Water Report 63/06)

Manoj S, Thirumurugan M, Elango L (2019) Hydrogeochemical modelling to understand the surface water-groundwater interaction around a proposed uranium mining site. J Earth Syst Sci 128(3):49. https://doi.org/10.1007/s12040-019-1078-9

McCallum JL, Cook PG, Simmons CT (2015) Limitations of the use of environmental tracers to infer groundwater age. Groundwater 53(Suppl 1):56-70. https://doi.org/10.1111/gwat.12237

McCallum JL, Cook PG, Dogramaci S, Purtschert R, Simmons CT, Burk L (2017) Identifying modern and historic recharge events from tracer-derived groundwater age distributions. Water Resour Res 53(2):1039-1056. https://doi.org/10.1002/2016wr019839

Meredith K, Han L, Hollins S, Cendón D, Jacobsen G, Baker A (2016) Evolution of chemical and isotopic composition of inorganic carbon in a complex semi-arid zone environment: consequences for groundwater dating using radiocarbon. Geochim Cosmochim Acta 188:352-367

Middlemis H, Peeters L (2018) Uncertainty analysis - Guidance for groundwater modelling within a risk management framework. A report prepared for the Independent Expert Scientific Committee on Coal Seam Gas and Large Coal Mining Development through the Department of the Environment and Energy, Commonwealth of Australia

Office of Water Science (2020) Environmental water tracers in environmental impact assessments for coal seam gas and large coal mining evelopments-factsheet. Prepared by the Office of Water Science for the Independent Expert Scientific Committee on Coal Seam Gas and Large Coal Mining Development, Canberra

Opitz J, Timms W (2016) Mine water discharge quality-a review of classification frameworks. Proc, IMWA: 17-26

Parizi HS, Samani N (2014) Environmental Isotope Investigation of groundwater in the Sarcheshmeh copper mine area. Iran Mine Water Environ 33(2):97-109. https://doi.org/10.1007/ s10230-014-0277-5

Pearson F Jr, White D (1967) Carbon 14 ages and flow rates of water in Carrizo Sand, Atascosa County. Texas Water Resour Res 3(1):251-261

Phillips F (2013) Chlorine-36 dating of old groundwater. Chapter 6. Isotope methods for dating old groundwater

Plummer L, Busenberg E (2006) Chlorofluorocarbons in aquatic environments. Use of chlorofluorocarbons in hydrology: a guidebook

Plummer L, Glynn P (1992) Radiocarbon dating in groundwater systems. MooN 100(4): 1

Plummer L, Glynn P (2013) Isotope methods for dating old groundwater. International Atomic Energy Agency:33-89

Plummer LN, Busenberg E, Cook PG (2006) Principles of chlorofluorocarbon dating. Use of chlorofluorocarbons in hydrology-a guidebook: $17-29$

Plummer L, Sanford W, Glynn P (2013) Characterization and conceptualization of groundwater flow systems. Chapter 2. Isotope methods for dating old groundwater 
Qian J, Tong Y, Ma L, Zhao W, Zhang R, He X (2017) Hydrochemical characteristics and groundwater source identification of a multiple aquifer system in a coal mine. Mine Water Environ 37(3):528540. https://doi.org/10.1007/s10230-017-0493-x

Ritterbusch F, Ebser S, Welte J, Reichel T, Kersting A, Purtschert R, Aeschbach-Hertig W, Oberthaler M (2014) Groundwater dating with atom trap trace analysis of ${ }^{39} \mathrm{Ar}$. Geophys Res Lett 41(19):6758-6764

Russo A (2019) Water resource evaluation - resource developmentmesa $\mathrm{H}$ : $\mathrm{H} 3$ hydrogeological assessment

Sayed SAS, Saeedy HS, Székely F (1992) Hydraulic parameters of a multilayered aquifer system in Kuwait City. J Hydrol 130(1):49_ 70. https://doi.org/10.1016/0022-1694(92)90103-3

Sophocleous M (2002) Interactions between groundwater and surface water: the state of the science. Hydrogeol J 10(1):52-67. https:// doi.org/10.1007/s10040-001-0170-8

Stellato L, Terrasi F, Marzaioli F, Belli M, Sansone U, Celico F (2013) Is ${ }^{222} \mathrm{Rn}$ a suitable tracer of stream-groundwater interactions? A case study in central Italy. Appl Geochem 32:108-117. https://doi. org/10.1016/j.apgeochem.2012.08.022

Suckow A (2013) System analysis using multitracer approaches. Ch 9, isotope methods for dating old groundwater. https://www-pub. iaea.org/MTCD/Publications/PDF/Pub1587_web.pdf

Suckow A (2014) The age of groundwater-definitions, models and why we do not need this term. Appl Geochem 50:222-230

Suckow A, Deslandes A, Raiber M, Taylor AR, Davies P, Gerber C, Leaney F (2019) Reconciling contradictory environmental tracer ages in multi-tracer studies to characterize the aquifer and quantify deep groundwater flow: an example from the Hutton Sandstone,
Great Artesian Basin, Australia. Hydrogeol J 28(1):75-87. https:// doi.org/10.1007/s10040-019-02042-8

Tammetta P (2015) Estimation of the change in hydraulic conductivity above mined longwall panels. Groundwater 53(1):122-129. https://doi.org/10.1111/gwat.12153

Tammetta P (2016) Estimation of the change in storage capacity above mined longwall panels. Groundwater 54(5):646-655. https://doi. org/10.1111/gwat.12405

Timms W, Acworth I, Hartland A, Laurence D (2012) Leading practices for assessing the integrity of confining strata: application to mining and coal seam gas extraction. In: Lund MA, Wyse L (eds) McCullough CD. Proc, IMWA Symp, pp 139-148

Vermeulen PD, Burger M, van Wyk A, Lukas E (2014) Using environmental isotopes in a coal mine and a gold mine to determine groundwater interaction. Mine Water Environ 33(1):15-23. https://doi.org/10.1007/s10230-013-0245-5

Wolkersdorfer C, Nordstrom DK, Beckie RD, Cicerone DS, Elliot T, Edraki M, Valente T, França SCA, Kumar P, Lucero RAO, Soler i Gil A, (2020) Guidance for the integrated use of hydrological, geochemical, and isotopic tools in mining operations. Mine Water Environ 39(2):204-228. https://doi.org/10.1007/ s10230-020-00666-x

Younger PL, Wolkersdorfer C (2004) Mining impacts on the fresh water environment: technical and managerial guidelines for catchment scale management. Mine Water Environ 23:S2

Zhang Q, López DL (2019) Use of time series analysis to evaluate the impacts of underground mining on the hydraulic properties of groundwater of Dysart Woods. Ohio Mine Water Environ 38(3):566-580. https://doi.org/10.1007/s10230-019-00619-Z 